Eskişehir Osmangazi Üniversitesi Mühendislik ve Mimarlık Fakültesi Dergisi 27(2), 77 - 84, 2019
Journal of Engineering and Architecture Faculty of

Eskisehir Osmangazi University 27(2), 77 - 84, 2019

\title{
MULTI-CRITERIA DECISION MAKING FOR CEMENT MORTAR MIXTURE SELECTION BY FUZZY TOPSIS
}

\author{
Eyyup GULBANDILAR ${ }^{1 *}$, Serel OZMEN AKYOL ${ }^{2}$, Yilmaz KOCAK ${ }^{3}$
}
${ }^{1}$ Eskisehir Osmangazi University, Faculty of Engineering and Architecture, Meselik Campus,
Department of Computer Engineering, 26480 Eskisehir,
ORCID No : http://orcid.org/0000-0001-5559-5281
${ }^{2}$ Eskișehir Osmangazi University, Sivrihisar Vocational School, Sivrihisar, Eskisehir, ORCID No : http://orcid.org/0000-0002-5344-4065

${ }^{3}$ Düzce University, Faculty of Technology, Konuralp Campus, Department of Civil Engineering, 81620 Düzce, ORCID No : http://orcid.org/0000-0002-5281-5450

\begin{tabular}{l}
\hline Keywords \\
\hline Fuzzy TOPSIS, \\
Multi-Criteria Decision \\
Making, \\
Cement mortar, \\
Compressive strength.
\end{tabular}

DOI : http://dx.doi.org/10.31796/ogummf.535998

\begin{abstract}
Cement mortar mixture consists of different materials as the content. The materials which make up this mixture and the selection of this mixture have a vital proposition for the constructions in which this mixture is used. In this selection process, it is very complicated to decide which one material and how to use in the selection. Fuzzy decisionmaking theory is a very useful method that can be used in such decision-making problems. In this study, it was preferred to use the fuzzy TOPSIS (Technique for Order Preference by Similarity to Ideal Solution) method to find the best cement mortar mixture. For this purpose, the optimum sorting was done for 40 alternatives using five criteria. These five criteria used are; The age of the samples (days), fly ash (FA), silica fume (SF), compressive strength (MPa) and ration of FA+SF mixtures. As a result, this study shows that the presented fuzzy TOPSIS model is able to effectively evaluate fuzziness in the multi-criteria decision process.
\end{abstract}

\section{BULANIK TOPSIS ILE ÇIMENTO HARCI KARIŞIMI SEÇIMI İÇIN ÇOKLU KRITERLI KARAR} VERME

\begin{tabular}{l}
\hline Anahtar Kelimeler \\
\hline Bulanık TOPSIS, \\
Çok Kriterli Karar Verme, \\
Cimento Karışımı, \\
Basınç dayanımı
\end{tabular}

Öz

Çimento harcı karışımı, içerik olarak farklı malzemelerden oluşmaktadır. Bu karışımı oluşturan malzemeler ve bu karışımın seçimi, bu karışımın kullanıldığı yapılar için hayati öneme sahiptir. Bu seçim sürecinde hangi malzemenin seçileceğine ve nasıl kullanılacağına karar vermek çok karmaşıktır. Bulanık karar verme teorisi, bu tür karar verme problemlerinde kullanılabilecek çok kullanışlı bir yöntemdir. Bu araştırmada, en iyi çimento harcı karışımını bulmak için bulanık TOPSIS yönteminin kullanılması tercih edilmiştir. Bu amaçla, beş kriter kullanılarak 40 adet alternatif için ideal sıralama yapılmıştır. Kullanılan bu beş kriter; numunelerin yaşı (gün), uçucu kül (FA), silis dumanı (SF), basınç dayanımı (MPa) ve FA + SF karışımları oranıdır. Sonuç olarak, bu çalışma sunulan bulanı TOPSIS modelinin çok kriterli karar sürecinde belirsizliği etkili bir şekilde değerlendirebildiğini göstermektedir.

\begin{tabular}{llll}
\hline Araştırma Makalesi & \multicolumn{3}{c}{ Research Article } \\
Başvuru Tarihi & $: 05.03 .2019$ & Submission Date & $: 05.03 .2019$ \\
Kabul Tarihi & $: 13.06 .2019$ & Accepted Date & $: 13.06 .2019$ \\
\hline
\end{tabular}

\section{Introduction}

In recent years, in many studies were assessed the effects of the partial chancing of cement by different types of additions. The added materials are usually trass, blast furnace slag, burned clay, silica fume, zeolite, fly ash, volcanic tuff and metakaolin (Behnood and Ziari,
2008; Kocak, 2010). Additional materials of cementitious usage in concrete and cement technology are preferred because of economic, technical and environmental reasons (Fu et al., 2002; Subasi, 2009; Worrell, Martin and Price, 2000). These cement materials consist of silica fume and fly ash.

${ }^{*}$ Corresponding Author; e-mail: egulbandilar@ogu.edu.tr 
Eskişehir Osmangazi Üniversitesi Mühendislik ve Mimarlık Fakültesi Dergisi 27(2), 77 - 84, 2019

Fly ash is a by-product of coal-fired power plants, which is obtained by separating the powder-burning power plant from flue gas. There are two general classes of fly ash as defined by ASTM C618: class C; high-calcium fly ash and class F; low-calcium fly ash. The on burning conditions and coal quality used determine the its chemical and physical properties (Behnood and Ziari, 2008). Fly ash is added to concretes or directly to mortars or cement of Portland (PC). For different purposes, it is added to the cement as an additive material during the production phase (Aruntas, 2006). The hydration heat is reduced by the use of fly ash, the alkali-silicate reactions are blocked, when used as a cement replacement in the concrete and also the durability is increased. It also contributes to cement and concrete mortars compressive strength by filler effects and pozzolanic (Neville, 2006; Saraswathy, Muralidharan, Thangavel and Srinivasan, 2003). In addition, the use of fly ash partially displaces the production of other concrete components. which in turn reduces $\mathrm{CO}_{2}$ emissions, protects resources and significantly save energy (Saridemir, 2009). Moreover, the addition of fly ash improves the chemical resistance of the material and contributes significantly to its workability (Garces, Andion, Zornoza, Bonilla and Paya, 2010).

Silica fume obtained by reduction of high-purity quartz with coal in electric arc furnaces in ferrosilicon alloys and silicon metal production (Neville, 2006), improves concrete properties when used as an additive material or it can be used a cement replacement for reducing the cement (Nochaiya, Wongkeo and Chaipanich, 2010). Due to the alkali-silicate reactions, silica fume can result in matrix expansion (Maas, Ideker and Juenger, 2007). While the resistance of concrete against corrosion is increasing, the permeability of silica fume is decreasing (Jo, Kim, Tae and Park, 2007; Qing, Zenan, Deyu and Rongshen, 2007). Furthermore, silica fume contributes to cement and concrete mortars compressive strength and durability (Song, Pack, Nam, Jong and Saraswathy, 2010).

In recent years, fuzzy multi-criteria decision-making methods have become popular and many researchers have used it to solve different problems in many engineering applications, including civil engineering. Different methods are used according to the aim. In the study which Multi-criteria decision-making applications in civil engineering, indicates on MCDM application fields (Zavadskas, Antuchevičienè and Kapliński, 2015). In the study which evaluated the sustainable decisionmaking in civil engineering, multiple-criteria decisionmaking (MCDM) theories were emphasized (Zavadskas, Antuchevičienè, Vilutiene and Adeli, 2018). Chen (1997) has solved the problem of selecting materials for tool steel with a new method. In his study, he used linguistic terms to evaluate different criteria importance weights
Journal of Engineering and Architecture Faculty of Eskisehir Osmangazi University 27(2), 77 - 84, 2019

and alternatives under fuzzy environment. There are used 5 alternative materials and 1 objective and 6 subjective criteria. The weights of all criteria and the ratings of the candidate alternatives as tool steel materials for these criteria are represented using trapezoidal fuzzy numbers.

Ozmen (2012) used fuzzy decision methods for selecting the ideal material for marine environments. In this study, there are 8 alternative materials for using marine environments and 4 criteria and 4 sub-criteria. Selection of the material to be used in marine ambiances is provided with fuzzy TOPSIS approach. Simsek, Ic and Simsek (2013) used TOPSIS-based Taguchi optimization method for determining the ideal mixture rates for high strength self-compacting concrete (HSSCC) in a readymixed concrete plant. The criteria used when evaluating with the TOPSIS-based Taguchi approach in the study; T50 time, average convective heat transfer coefficient, the compressive strength, the percentage of air content, the separating tensile strength, the water absorption, the production cost and the slump flow value.

Ertugrul and Karakasoglu (2009) proposed a model using for evaluating the performance of the 15 Turkish cement firms in the Istanbul Stock Exchange. The ranking is determined according to firms financial tables results by Technique for Order Preference by Similarity to Ideal Solution (TOPSIS) and Fuzzy Analytic Hierarchy Process (FAHP) methods.

In this study, it is aimed to select the ideal cement mortar mixture according to the satisfaction criteria weights by using Fuzzy TOPSIS method. For this purpose, 40 different cement mortar mixture specimens were evaluated. We founded the best mixture of cement mortar with the five criteria and 40 alternatives. These five criteria are; the age of samples (days), fly ash (FA), compressive strength (MPa), silica fume (SF) and FA+SF. The TOPSIS method is used to compare these cement mortar mixture specimens and the best alternative was selected according to the criteria importance weight values evaluated by the decision makers.

\section{Experimental Study}

In this study, the PC (CEM I $42.5 \mathrm{R}$ according to TS EN 197-1), FA, SF, standard aggregate and water were used these materials for cement production. PC were produced by Bursa Cement Plant in Turkey. FA which provided from the Kutahya Seyitomer Thermal Power Plant in Turkey has been mixed as small components for cement produce. Also, the SF was attained from the Antalya Etibank electro-ferrochrome business in Turkey. The CEM standard aggregate was arranged by SET Trakya Cement industry according to TS EN 196-1. Cement components are set using tap water in BursaKestel province. 
Eskişehir Osmangazi Üniversitesi Mühendislik ve Mimarlık Fakültesi Dergisi 27(2), 77 - 84, 2019

Based on the PC, the experiment is designed using eight different combinations. The total weight of experimental samples is kept constant, three different samples by adding FA is obtained by $10 \%, 20 \%$ and $30 \%$ of the total weight into the PC sample. Similarly, two different samples by adding SF is achieved by mixed $5 \%$ to $10 \%$ of the total weight. For the investigating the properties of triplicate mixtures, The FA and SF are obtained by adding $10 \%$ and $20 \%$ of total weight in to the PC sample, respectively. In addition, a sample mixture was obtained by displacing the FA and SF ratios. Finally, FA and SF amounts are mixed equally. The samples used in the study were obtained from the experiments in which the chemical and physical properties were analyzed made by Kocak (2010). In this study, the output parameter that compressive strength obtained from experiments is used as criteria.

\section{Fuzzy TOPSIS Method}

For most situations that need to be decided, there is no single criterion. Like these, in situations where a singlecriterion approach does not provide a solution, are expressed by multi-criteria decision-making methods (MCDM) (Kelemenis and Askounis, 2010). There are MCDMs with different algorithms in the literature (Lin, Zhangb and Meng, 2015; Ma, Lu and Zhang, 2010; Maity and Chakraborty, 2015). And there are several methods as AHP, ELECTRE, VIKOR, TOPSIS. TOPSIS, one of these methods, developed by Hwang and Yoon, is recommended to approach the selection of the most ideal alternative. The method's focused on the concept that the chosen alternative should have the shortest distance from the positive ideal solution. Ideal solution maximizes the benefit criteria; and the farthest from the negative ideal solution and minimizes the benefit criteria (Dalalah, Hayajneh and Batieha, 2011).

In this paper, all the fuzzy evaluation processes have defined using triangular fuzzy numbers. Thus, before moving onto the fuzzy TOPSIS method, information about the triangular fuzzy number term used in the method will be given.

Triangular fuzzy numbers can be expressed as $(l, m, u)$ in Figure 1; being a specific type of fuzzy numbers defined with three floating point numbers. Parameters $(l, m, u)$ express minimum possible number value, the most probable value, and maximum possible value in order.

When processing with a triangular number, linear representation of the number with regard to its right and left values are as such Eq. (1);
Journal of Engineering and Architecture Faculty of Eskisehir Osmangazi University 27(2), 77 - 84, 2019

$$
\mu(x)= \begin{cases}0 & \text { for } x<l, \\ \frac{x-l}{m-l} & \text { for } l \leq x \leq m, \\ \frac{u-x}{u-m} & \text { for } m \leq x \leq u, \\ 0 & \text { for } x \geq u .\end{cases}
$$

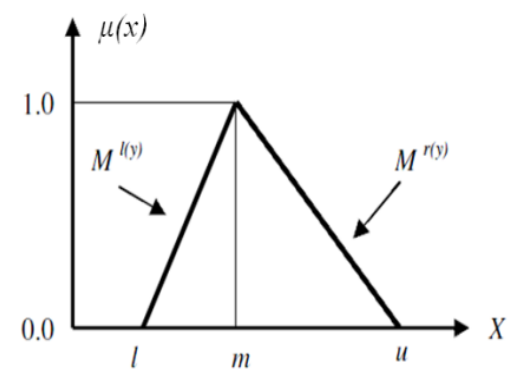

Figure 1. Fuzzy triangular number $(l, m, u)$

The method is the arrangement of factoring the distance to the ideal solution (TOPSIS). When providing a solution with this method, the distance of all positive and negative alternatives to the ideal solution is calculated. The case of a selected alternative being in the shortest distance to the positive ideal solution and in the longest distance to the negative ideal solution at the same time forms the basis of TOPSIS approach (Chen, 2000).

Steps of the methods are briefly explained:

Step 1: Decision maker group and evaluating criteria are determined.

Step 2: Linguistic terms in Table 1 for criteria to be weighted and linguistic scores in Table 2 for alternatives to be evaluated are generated.

Table 1

Linguistic terms and their corresponding fuzzy numbers of the criteria

\begin{tabular}{lc}
\hline \multicolumn{1}{c}{ Linguistic Terms } & Fuzzy Numbers \\
\hline Very important (VI) & $(0.75,1.0,1.0)$ \\
Important (I) & $(0.5,0.75,1.0)$ \\
Fair (F) & $(0.25,0.5,0.75)$ \\
Unimportant (U) & $(0,0.25,0.5)$ \\
Very unimportant (VU) & $(0,0,0.25)$ \\
\hline
\end{tabular}

Table 2

Linguistic terms and their corresponding fuzzy numbers of the alternatives

\begin{tabular}{lc}
\hline Linguistic Terms & Fuzzy Numbers \\
\hline Very Poor (VP) & $(1,1,3)$ \\
Poor (P) & $(1,3,5)$ \\
Fair (F) & $(3,5,7)$ \\
Good (G) & $(5,7,9)$ \\
Very Good (VG) & $(7,9,9)$ \\
\hline
\end{tabular}


Eskişehir Osmangazi Üniversitesi Mühendislik ve Mimarlık Fakültesi Dergisi 27(2), 77 - 84, 2019

Step 3: Evaluations that $\mathrm{N}$ amounts of decision makers carry out for criteria and alternatives are combined. Here, $\tilde{x}_{i j}^{N}$ indicates the evaluation of $\mathrm{N}$ decision maker and $\widetilde{w}_{j}^{N}$; indicates the significance of $\mathrm{N}$ decision maker.

$$
\begin{aligned}
& \widetilde{x}_{i j}=\frac{1}{N}\left[\tilde{x}_{i j}^{1} \otimes \tilde{x}_{i j}^{2} \otimes \ldots \otimes \tilde{x}_{i j}^{N}\right] \\
& \widetilde{w}_{j}=\frac{1}{N}\left[\widetilde{w}_{j}^{1} \otimes \widetilde{w}_{j}^{2} \otimes \ldots \otimes \widetilde{w}_{j}^{N}\right]
\end{aligned}
$$

Step 4: The Decision Problem is presented in matrix format in Equation 4 after a single value for all the criteria and alternatives is generated. Here, $\tilde{\mathrm{x}}_{\mathrm{ij}}=$ $\left(\mathrm{a}_{\mathrm{ij}}, \mathrm{b}_{\mathrm{ij}}, \mathrm{c}_{\mathrm{ij}}\right)$ and $\widetilde{\mathrm{w}}_{\mathrm{j}}=\left(\mathrm{w}_{\mathrm{j} 1}, \mathrm{w}_{\mathrm{j} 2}, \mathrm{w}_{\mathrm{j} 3}\right)$ being triangular fuzzy numbers, $\widetilde{D}$ indicates fuzzy decision matrix, and $\widetilde{W}$ indicates fuzzy weights matrix.

$$
\widetilde{D}=\left[\begin{array}{cccc}
\tilde{x}_{11} & \tilde{x}_{12} & \ldots & \tilde{x}_{1 n} \\
\tilde{x}_{21} & \tilde{x}_{22} & \ldots & \tilde{x}_{2 n} \\
\vdots & \vdots & \ldots & \vdots \\
\tilde{x}_{m 1} & \tilde{x}_{m 2} & \ldots & \tilde{x}_{m n}
\end{array}\right] \quad \widetilde{W}=\left[\widetilde{w}_{1}, \widetilde{w}_{2}, \ldots, \widetilde{w}_{n}\right]
$$

Step 5: The step after the generation of decision matrix is the normalization of the decision matrix. The fuzzy decision matrix is normalized with the help of Equation 6 and 7 and normalized fuzzy decision matrix $\widetilde{R}$ is obtained.

$$
\tilde{R}=\left[\tilde{r}_{i j}\right]_{m x n}
$$

and $\mathrm{C}$, being the profit and cost criteria;

$$
\begin{aligned}
& \tilde{r}_{i j}=\left(\frac{a_{i j}}{c_{j}^{*}}, \frac{b_{i j}}{c_{j}^{*}}, \frac{c_{i j}}{c_{j}^{*}}\right), \quad j \in B, c_{j}^{*}=\max _{i} c_{i j,} \quad j \in B \\
& \tilde{r}_{i j}=\left(\frac{a_{j}^{-}}{c_{i j}}, \frac{a_{j}^{-}}{b_{i j}}, \frac{a_{j}^{-}}{a_{i j}}\right), \quad j \in C, a_{j}^{-}=\min _{i} a_{i j,} \quad j \in C
\end{aligned}
$$

calculated as. Here, $\tilde{r}_{i j},(\forall i, j)$ resemble normalized triangular fuzzy numbers.

Step 6: Taking the fact that each decision criteria might have different significance into factor after the normalized fuzzy deciding matrix is generated, the weighted normalized fuzzy decision matrix is generated in this manner:

$$
\tilde{V}=\left[\tilde{v}_{i j}\right]_{m x n} \quad i=1,2, \ldots, m \quad j=1,2, \ldots, n
$$

Here it is expressed as, $\tilde{v}_{i j}=\tilde{r}_{i j}(.) \widetilde{w}_{i j}$.

Step 7: After normalized fuzzy decision matrix is generated, fuzzy positive ideal solution (FPIS, $A^{*}$ ) and fuzzy negative ideal solution (FNIS, $\bar{A}$ ) are identified as:
Journal of Engineering and Architecture Faculty of Eskisehir Osmangazi University 27(2), 77 - 84, 2019

$$
A^{*}=\left(\tilde{v}_{1}^{*}, \tilde{v}_{2}^{*}, \ldots, \tilde{v}_{n}^{*}\right) \quad A^{-}=\left(\tilde{v}_{1}^{-}, \tilde{v}_{2}^{-}, \ldots, \tilde{v}_{n}^{-}\right)
$$

Here it is expressed as, $\tilde{v}_{j}^{*}=(1,1,1)$ and $\tilde{v}_{j}^{-}=$ $(0,0,0) j=1,2, \ldots, n$

Step 8: And then, the distance of each alternative to the positive ideal solution $\left(\mathrm{A}^{*}\right)$ and negative ideal solution $(\bar{A})$ is calculated. Here, $d(.$,$) indicates the distance$ between two fuzzy numbers and is calculated with the help of vertex method.

$$
\begin{aligned}
& d_{i}^{*}=\sum_{j=1}^{n} d_{v}\left(\tilde{v}_{i j}, \tilde{v}_{j}^{*}\right) \quad i=1,2, \ldots, m \\
& d_{i}^{-}=\sum_{j=1}^{n} d_{v}\left(\tilde{v}_{i j}, \tilde{v}_{j}^{-}\right) \quad i=1,2, \ldots, m
\end{aligned}
$$

Step 9: Affinity parameters of each alternative are calculated.

$$
C C_{i}=\frac{d_{i}^{-}}{d_{i}^{*}+d_{i}^{-}} \quad, i=1,2, \ldots, m
$$

Step 10: With the action of distance parameters are sorted descending, preference order of the alternatives is obtained (Chen, 2000).

According to these rules, 40 cement mortar mixture species $\left(\mathrm{A}_{1} \ldots \mathrm{A}_{40}\right)$ are evaluated with fuzzy TOPSIS method. For this purpose, 5 criteria which were determined by the decision maker, are evaluated. The cement mortar mixture selection criteria and the importance weights of the criteria are shown in Table 3 and Table 4, respectively.

Table 3

Selection criteria

\begin{tabular}{ll}
\hline Subjective Criteria & Objective Criteria \\
\hline Age of samples (days) & Compressive strength \\
$\left(\mathrm{C}_{1}\right)$ & $(\mathrm{MPa})\left(\mathrm{C}_{5}\right)$ \\
$\mathrm{FA}\left(\mathrm{C}_{2}\right)$ & \\
SF $\left(\mathrm{C}_{3}\right)$ & \\
FA+SF $\left(\mathrm{C}_{4}\right)$ & \\
\hline
\end{tabular}

(8)

Table 4

The importance weights of the five criteria

\begin{tabular}{cc}
\hline Criteria & Decision-maker \\
\hline $\mathrm{C}_{1}$ & Very Important (VI) \\
$\mathrm{C}_{2}$ & Important (I) \\
$\mathrm{C}_{3}$ & Unimportant (U) \\
$\mathrm{C}_{4}$ & Fair (F) \\
$\mathrm{C}_{5}$ & Very Important (VI) \\
\hline
\end{tabular}


Eskişehir Osmangazi Üniversitesi Mühendislik ve Mimarlık Fakültesi Dergisi 27(2), 77 - 84, 2019

In this study, linguistic terms used in the evaluation of alternatives and criteria were indicated by positive triangular fuzzy numbers. The ratings of the candidate cement mortar mixtures under the five criteria are shown in Table 5. The decision matrix is calculated with linguistic terms and their fuzzy numbers values of the alternatives.

Table 5

Ratings of the candidate cement mortar mixtures

\begin{tabular}{|c|c|c|c|c|c|}
\hline $\begin{array}{c}\text { Candidate } \\
\text { Alternatives }\end{array}$ & $\mathrm{C}_{1}$ & $\mathrm{C}_{2}$ & $\mathrm{C}_{3}$ & $\mathrm{C}_{4}$ & $\begin{array}{c}\mathrm{C}_{5} \\
(\mathrm{MPa}) \\
\end{array}$ \\
\hline A1 & $P$ & $P$ & $P$ & VP & 32,7 \\
\hline $\mathrm{A} 2$ & $\mathrm{~F}$ & VG & VG & VP & 59,5 \\
\hline A3 & F & F & $\mathrm{F}$ & VP & 50,9 \\
\hline A4 & G & VG & VG & VP & 62,7 \\
\hline$A 5$ & VG & F & $\mathrm{F}$ & VP & 64,6 \\
\hline ת & VG & VP & VP & VP & 25,9 \\
\hline A7 & VP & VP & VP & VP & 11,7 \\
\hline A8 & VP & $\mathrm{F}$ & VG & VG & 23,3 \\
\hline A9 & VP & $\mathrm{P}$ & $\mathrm{F}$ & VG & 19,2 \\
\hline A10 & $P$ & VG & VG & VP & 46,5 \\
\hline A11 & VG & VG & VG & VP & 63,6 \\
\hline A12 & VG & $\mathrm{P}$ & $\mathrm{P}$ & VP & 52,3 \\
\hline A13 & VP & $\mathrm{F}$ & $\mathrm{F}$ & VP & 24 \\
\hline A14 & VP & $\mathrm{P}$ & $\mathrm{P}$ & VP & 19,5 \\
\hline A15 & VP & $\mathrm{F}$ & G & $\mathrm{F}$ & 26,1 \\
\hline A16 & $\mathrm{P}$ & F & F & VP & 39 \\
\hline A17 & $\mathrm{F}$ & $\mathrm{P}$ & $\mathrm{F}$ & VG & 52,9 \\
\hline A18 & G & $\mathrm{P}$ & $P$ & VP & 50,8 \\
\hline A19 & $\mathrm{G}$ & VP & VP & VP & 23,1 \\
\hline A20 & VG & $\mathrm{G}$ & VG & $\mathrm{F}$ & 63,2 \\
\hline
\end{tabular}

Table 6.

Closeness coefficient table

\begin{tabular}{ccc}
\hline $\begin{array}{c}\text { Candidate } \\
\text { Alternatives }\end{array}$ & $\mathrm{CC}_{\mathrm{i}}$ & Ranking \\
\hline A1 & 0,37678 & 35 \\
A2 & 0,47528 & 12 \\
A3 & 0,43940 & 22 \\
A4 & 0,49382 & 5 \\
A5 & 0,47806 & 10 \\
A6 & 0,40094 & 31 \\
A7 & 0,30161 & 40 \\
A8 & 0,40934 & 29 \\
A9 & 0,37957 & 34 \\
A10 & 0,44662 & 19 \\
A11 & 0,50486 & 3 \\
A12 & 0,44860 & 17 \\
A13 & 0,37387 & 37 \\
A14 & 0,34097 & 38 \\
A15 & 0,39712 & 32 \\
A16 & 0,40825 & 30 \\
A17 & 0,45009 & 16 \\
A18 & 0,43599 & 23 \\
A19 & 0,38514 & 33 \\
A20 & 0,50757 & 1 \\
\hline
\end{tabular}

\begin{tabular}{cccccc}
\hline $\begin{array}{c}\text { Candidate } \\
\text { Alternatives }\end{array}$ & $\mathrm{C}_{1}$ & $\mathrm{C}_{2}$ & $\mathrm{C}_{3}$ & $\mathrm{C}_{4}$ & $\begin{array}{c}\mathrm{C}_{5} \\
(\mathrm{MPa})\end{array}$ \\
\hline A21 & VG & $\mathrm{F}$ & $\mathrm{G}$ & $\mathrm{F}$ & 63,8 \\
A22 & $\mathrm{P}$ & $\mathrm{F}$ & $\mathrm{G}$ & $\mathrm{F}$ & 40,3 \\
A23 & $\mathrm{F}$ & $\mathrm{G}$ & $\mathrm{VG}$ & $\mathrm{F}$ & 57,8 \\
A24 & VP & VG & VG & VP & 29,7 \\
A25 & VP & G & VG & F & 26,3 \\
A26 & P & F & VG & VG & 37,8 \\
A27 & F & F & F & VP & 52 \\
A28 & F & P & P & VP & 48 \\
A29 & F & F & VG & VG & 54,3 \\
A30 & G & G & VG & F & 65,2 \\
A31 & G & F & VG & VG & 60,6 \\
A32 & G & F & G & F & 58,2 \\
A33 & G & P & F & VG & 57,5 \\
A34 & P & VP & VP & VP & 14,7 \\
A35 & P & G & VG & F & 42,6 \\
A36 & P & P & F & VG & 33 \\
A37 & F & VP & VP & VP & 32,3 \\
A38 & F & F & G & F & 53,2 \\
A39 & VG & F & VG & VG & 62,6 \\
A40 & VG & P & F & VG & 58,4 \\
\hline & & & & &
\end{tabular}

Journal of Engineering and Architecture Faculty of Eskisehir Osmangazi University 27(2), 77 - 84, 2019

The matrix of normalized alternative and the matrix of finally the weighted normalized alternative are calculated with Equations 5-8. The distances of each candidate cement mortar mixture from the ideal and the rank the alternatives are calculated. The closeness coefficient (CC) values of the alternatives are shown Table 6.

\begin{tabular}{ccc}
\hline $\begin{array}{c}\text { Candidate } \\
\text { Alternatives }\end{array}$ & $\mathrm{CC}_{\mathrm{i}}$ & Ranking \\
\hline A21 & 0,49360 & 7 \\
A22 & 0,42838 & 24 \\
A23 & 0,47740 & 11 \\
A24 & 0,41402 & 27 \\
A25 & 0,41489 & 25 \\
A26 & 0,43985 & 21 \\
A27 & 0,44041 & 20 \\
A28 & 0,41466 & 26 \\
A29 & 0,47274 & 13 \\
A30 & 0,49830 & 4 \\
A31 & 0,49368 & 6 \\
A32 & 0,47943 & 9 \\
A33 & 0,47083 & 14 \\
A34 & 0,32858 & 39 \\
A35 & 0,44675 & 18 \\
A36 & 0,41159 & 28 \\
A37 & 0,37456 & 36 \\
A38 & 0,45875 & 15 \\
A39 & 0,50534 & 2 \\
A40 & 0,48213 & 8 \\
\hline
\end{tabular}


Eskișehir Osmangazi Üniversitesi Mühendislik ve Mimarlık Fakültesi Dergisi 27(2), 77 - 84, 2019
Journal of Engineering and Architecture Faculty of Eskisehir Osmangazi University 27(2), 77 - 84, 2019
The alternative that has the greatest value according to the alternative $\mathrm{CC}$ closest to the ideal. The ranking of the cement mortar mixture alternatives is shown Table 7.

Table 7.

Ranked Fuzzy TOPSIS results

\begin{tabular}{cc}
\hline Ranking & Candidate Alternatives \\
\hline 1 & A20 \\
2 & A39 \\
3 & A11 \\
4 & A30 \\
5 & A4 \\
6 & A31 \\
7 & A21 \\
8 & A40 \\
9 & A32 \\
10 & A5 \\
11 & A23 \\
12 & A2 \\
13 & A29 \\
14 & A33 \\
15 & A38 \\
16 & A17 \\
17 & A12 \\
18 & A35 \\
19 & A10 \\
20 & A27
\end{tabular}

\section{Results and Discussion}

The TOPSIS method can be used with linguistic variables, where alternatives are evaluated for multidecision criteria, and where group decisions are required. The reason for choosing the TOPSIS method in this study is the multitude of alternatives and a MCDM process.

In this study 40 cement mortar mixture species were evaluated for 5 criteria and the results were obtained. According to the closeness coefficients of the 40 alternatives examined in the study, the $A_{20}$ alternative appears to be the best result with the highest CC value. Thus, the best selection is cement mortar mixture is $A_{20}$. The $A_{7}$ is the worst alternative that can be selected according to the weight of criteria. It is seen that the alternative coefficients have a narrow range $(0,30161$ 0,50757 ) of convergence coefficients and that their coefficients of closeness are very close to each other. The best alternative chosen is determined by the criteria weighted by the decision-maker. Another decisionmaker may obtain a different selected alternative by evaluating the criterion weights of the alternative it satisfied to select. Fuzzy TOPSIS method facilitates the decision-making process in such cases where the qualities of the candidates are very close to each other and it is difficult to decide.

\section{Conclusion}

In this paper, TOPSIS method was used as a decision tool to solve the cement mortar selection problem. TOPSIS

\begin{tabular}{cc}
\hline Ranking & Candidate Alternatives \\
\hline 21 & A26 \\
22 & A3 \\
23 & A18 \\
24 & $\mathrm{~A} 22$ \\
25 & $\mathrm{~A} 25$ \\
26 & $\mathrm{~A} 28$ \\
27 & $\mathrm{~A} 24$ \\
28 & $\mathrm{~A} 36$ \\
29 & $\mathrm{~A} 8$ \\
30 & $\mathrm{~A} 16$ \\
31 & $\mathrm{~A} 6$ \\
32 & $\mathrm{~A} 15$ \\
33 & $\mathrm{~A} 19$ \\
34 & $\mathrm{~A} 9$ \\
35 & $\mathrm{~A} 1$ \\
36 & $\mathrm{~A} 37$ \\
37 & $\mathrm{~A} 13$ \\
38 & $\mathrm{~A} 14$ \\
39 & $\mathrm{~A} 34$ \\
40 & $\mathrm{~A} 7$ \\
\hline
\end{tabular}

method can be used for the selection the 2, 7, 28, 56 and 90 day's compressive strength values of cement mortars containing FA, SF and FA+SF. In this study, analysis has been made for a decision maker. The number of decision makers can be increased. It is possible to have multiple decision makers participate in the decision with different weights. Proximity coefficients of the alternatives were found, and alternatives were sorted according to these values. The ranking is based on the criteria weighted by the decision maker. The reason for choosing the fuzzy TOPSIS method is when selecting the best alternative to evaluate both the most suitable and the most unsuitable alternative together.

As a result, TOPSIS, which is used as a multi-criteria decision-making method, aims to find the best alternative among the alternatives according to the weight determined by the decision makers.

\section{Conflict of Interest}

No conflict of interest was declared by the authors.

\section{References}

Aruntas, H.Y. (2006). The potential of fly ash usage in construction sector, Journal of The Faculty of Engineering and Architecture of Gazi University, 21(1), 193-203. Retrieved from http://www.mmfdergi.gazi.edu.tr/article/view/10 $\underline{61000709}$ 
Eskișehir Osmangazi Üniversitesi Mühendislik ve Mimarlık Fakültesi Dergisi 27(2), 77 - 84, 2019

Behnood, A. \& Ziari, H. (2008). Effects of silica fume addition and water to cement ratio on the properties of high-strength concrete after exposure to high temperatures, Cement and Concrete Composites, 30, 106-112. doi: https://doi.org/10.1016/i.cemconcomp.2007.06.003

Chen, C.T. (2000). Extensions of the TOPSIS for group decision-making under fuzzy environment, Fuzzy Sets and Systems, 114, 1-9. doi: https://doi.org/10.1016/S0165-0114(97)00377-1

Chen, S.M. (1997). A new method for tool steel materials selection under fuzzy environment, Fuzzy Sets and Systems, 92, 265-274. doi: https://doi.org/10.1016/S0165-0114(96)00189-3

Dalalah, D., Hayajneh, M. \& Batieha, F. (2011). A fuzzy multi-criteria decision making model for supplier selection, Expert Systems with Applications, 38, 8384-8391.

https://doi.org/10.1016/j.eswa.2011.01.031

Ertugrul, I. \& Karakasoglu, N. (2009). Performance evaluation of Turkish cement firms with fuzzy analytic hierarchy process and TOPSIS methods, Expert Systems with Applications, 36, 702-715. doi: https://doi.org/10.1016/j.eswa.2007.10.014

Fu, X., Wang, Z., Tao, W., Yang, C., Hou, W., Dong, Y. \& Wu, $X$. (2002). Studies on blended cement with a large amount of fly ash, Cement and Concrete Research, 32(7), 1153-1159. doi: https://doi.org/10.1016/S0008-8846(02)00757-3

Garces, P., Andion, L. G., Zornoza, E., Bonilla, M. \& Paya, J. (2010). The effect of processed fly ashes on the durability and the corrosion of steel rebars embedded in cement-modified fly ash mortars, Cement and Concrete Composites, 32, 204-210. doi: https://doi.org/10.1016/i.cemconcomp.2009.11.006

Jo, B.W., Kim, C.H., Tae, G. and Park, J. B. (2007). Characteristics of cement mortar with nano-SiO2 particles, Construction and Building Materials, 21, 1351-1355. https://doi.org/10.1016/j.conbuildmat.2005.12.020

Kelemenis, A. \& Askounis, D. (2010). A new TOPSISbased multi-criteria approach to personnel selection, Expert Systems with Applications, 37 (7), 4999-5008. doi: https://doi.org/10.1016/j.eswa.2009.12.013

Kocak, Y. (2010). A study on the effect of fly ash and silica fume substituted cement paste and mortars, Scientific Research and Essays, 5(9), 990-998. Retrieved from https://academicjournals.org/article/article13806 22013 Kocak.pdf

Lin, J., Zhangb, Q. \& Meng, F. (2015). An approach for facility location selection based on optimal
Journal of Engineering and Architecture Faculty of Eskisehir Osmangazi University 27(2), 77 - 84, 2019

aggregation operator, Knowledge-Based Systems, 85, 143-158.

https://doi.org/10.1016/j.knosys.2015.05.001

Ma, J., Lu, J. \& Zhang, Z. (2010). Decider: A fuzzy multicriteria group decision support system, KnowledgeBased Systems, 23, 23-31. doi: https://doi.org/10.1016/j.knosys.2009.07.006

Maas, A.J., Ideker, J.H. \& Juenger, M.C.G. (2007). Alkali silica reactivity of agglomerated silica fume, Cement and Concrete Research, 37, 166-174. doi: https://doi.org/10.1016/j.cemconres.2006.10.011

Maity, S.R. \& Chakraborty, S. (2015). Tool steel material selection using PROMETHEE II method, International Journal of Advanced Manufacturing Technology, 78, 1537-1547. doi: https://doi.org/10.1007/s00170-014-6760-0

Neville, A. M. (2006). Properties of concrete, England: Pearson Education Limited.

Nochaiya, T., Wongkeo, W. \& Chaipanich, A. (2010). Utilization of fly ash with silica fume and properties of Portland cement-fly ash-silica fume concrete, Fuel, 89, 768-774. doi: https://doi.org/10.1016/i.fuel.2009.10.003

Ozmen, S. (2012). Material selection for marine environments by fuzzy decision method, M.Sc. Thesis, Marmara University, İstanbul, Turkey.

Qing, Y., Zenan, Z., Deyu, K. \& Rongshen, C. (2007). Influence of nano-SiO2 addition on properties of hardened cement paste as compared with silica fume, Construction and Building Materials, 21, 539545. doi: https://doi.org/10.1016/j.conbuildmat.2005.09.001

Saraswathy, V., Muralidharan, S., Thangavel, K. \& Srinivasan, S. (2003). Influence of activated fly ash on corrosion-resistance and strength of concrete, Cement and Concrete Composites, 25(7), 673-680. doi: https://doi.org/10.1016/S09589465(02)00068-9

Saridemir, M. (2009). Prediction of compressive strength of concretes containing metakaolin and silica fume by artificial neural network, Advances in Engineering Software, 40, 350-355. doi: https://doi.org/10.1016/j.advengsoft.2008.05.002

Simsek, B., Ic, Y.T \& Simsek, E.H. (2013). A TOPSIS-based Taguchi optimization to determine optimal mixture proportions of the high strength self-compacting concrete, Chemometrics and Intelligent Laboratory Systems, 125, 18-32. doi: https://doi.org/10.1016/j.chemolab.2013.03.012

Song, H.W., Pack, S.W., Nam, S.H., Jong, J.C. \& Saraswathy, V. (2010). Estimation of the permeability of silica 
Eskişehir Osmangazi Üniversitesi Mühendislik ve Mimarlık Fakültesi Dergisi 27(2), 77 - 84, 2019

fume cement concrete, Construction and Building Materials, 24, 315-321. doi: https://doi.org/10.1016/j.conbuildmat.2009.08.033

Subasi, S. (2009). Prediction of mechanical properties of cement containing class $\mathrm{C}$ fly ash by using artificial neural network and regression technique, Scientific Research and Essay, 4(4), 289-297. Retrieved from https://academicjournals.org/journal/SRE/articlefull-text-pdf/E1B7FD530019

Zavadskas, E., K., Antuchevičienè, J. \& Kapliński, O. (2015). Multi-criteria decision making in civil engineering. Part II - applications, Engineering Structures and Technologies, 7(4), 151-167. doi: https://doi.org/10.3846/2029882X.2016.1139664

Zavadskas, E.K., Antucheviciene, J., Vilutiene, T. \& Adeli, H. (2018). Sustainable decision-making in civil engineering, construction and building technology, Sustainability, 10(1), $14 . \quad$ doi: https://doi.org/10.3390/su10010014

Worrell, E., Martin, N. \& Price, L. (2000). Potential for energy efficiency improvement in the US cement industry, Energy, 25(12), 1189-1214. Retrieved from:https://www.sciencedirect.com/science/articl e/pii/S0360544200000426/pdfft?md5=06f989786 0252cdb11f1a3d00461b6bf\&pid=1-s2.0S0360544200000426-main.pdf
Journal of Engineering and Architecture Faculty of Eskisehir Osmangazi University 27(2), 77 - 84, 2019 